\title{
WAGENINGEN, CENTRE OF AGRICULTURAL SCIENCE IN THE NETHERLANDS
}

\author{
H. DE HAAN \\ Institute of Agricultural Plant Breeding, Wageningen
}

In 1876, a modest agricultural school was founded at Wageningen. It gradually developed into the present important centre of agricultural research and training in the Netherlands. It is the seat of the Agricultural University with its many laboratories and divisions. It is also the seat of various autonomous research institutes.

In general it can be said that the University is the training centre for free scientific research ${ }^{1}$ ). The autonomous institutes carry out research work more in the field of applied science, since their problems proceed from practice. Most autonomous institutes are government sponsored foundations coordinated in the National Council for Agricultural Research. A few are run under the auspices of industry.

Of late years research has become more important. Many new buildings have been erected, some are in course of construction and others have been planned.

\section{AgRicUltural RESEARCH}

Here follows a survey of the laboratories since the foundation of the Agricultural University in 1918.

\section{Divisions of the Agricultural University}

1922 Laboratory of Plant Physiological Research

1922 Microbiological Laboratory

1923 Horticultural Laboratory

1923 Laboratory of Phytopathology

1925 Institute of Agricultural Plant Breeding

1925 Division of Agricultural Machinery and Farm Buildings (moved to a new building in 1954)

1925 Laboratory of Animal Husbandry

1929 Laboratory of Genetics

1932 Laboratory of Soils and Fertilizers (destroyed during the war)

1933 Institute of Forestry (Extension)

1934 Laboratory of Botany

1935 Auditorium

1935 State Agricultural Library

1939 Laboratory of Tropical Agriculture

1941 Laboratory of Dairying

1948 Division of General and Agricultural Economics

1952 Division of Rural Home Economics

1953 Laboratory of Surveying

1) G. J. Vervelde, The training and function of the Dutch graduate agriculturist. Netherlands Journal of agricultural Science 3 (1955) 241-246. 


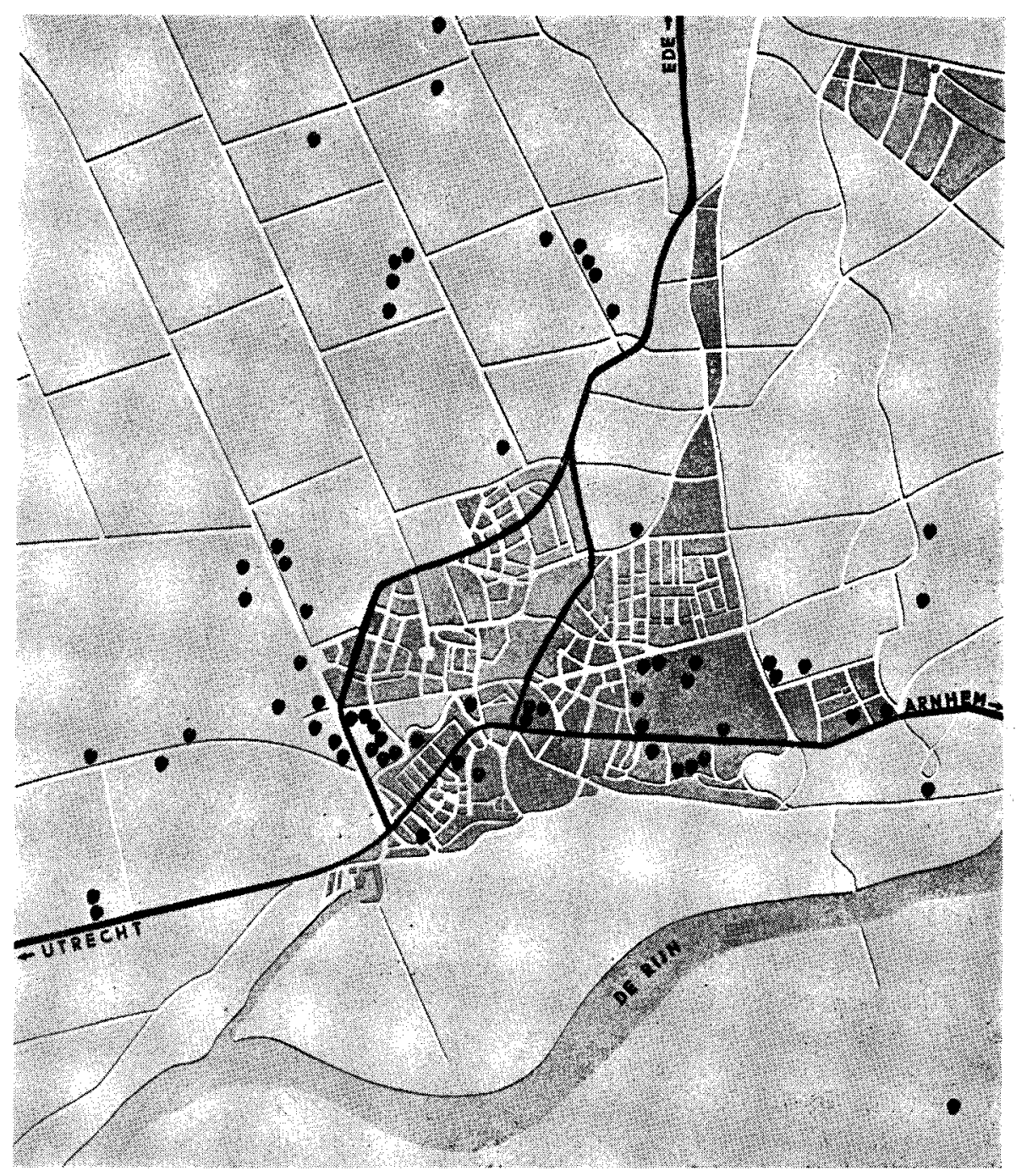

Fig. I Plan of Wageningen. The laboratories of the Agricultural University and the AUTONOMOUS INSTITUTES (BLACK DOTS IN THE FIGURE) ARE SCATTERED ABOUT IN' DIFFERENT BUILDINGS OVER a CONSIDERABLe aREA IN AND OUTSIDE THE TOWN. WAGENINGEN is Situated on the river Ruine (De Rijn) and has good road connections with Utrecht, Arnhem and the railway station Ede-Wageningen.

1953 Laboratory of Field Crop Husbandry

1954 Laboratory of Animal Physiology

1954 Division of Agricultural Machinery and Farm Buildings

1954 Technological Laboratory

1955 Experimental Farm of the Laboratory of Animal Physiology

1955 Division of Rural Sociology

1955 Division of Grassland Husbandry

1955 Division of Mathematics and Statistics

1956 Division of Land Drainage and Land Improvement

1956 Laboratory of Hydraulic Engineering and Irrigation 
Zoological Laboratory

1957 Laboratory of Soils and Fertilizers

1957 Laboratory of Virology

(New buildings for the Laboratories of Organic and of Physical and Colloid Chemistry)

\section{Autonomous Institutions}

Survey of the new institutions, some of which are housed in existing buildings.

1935 Central Experimental Field for Manuring of Fruit Trees "De Lange Ossekampen"

1939 Central Institute of Agricultural Research (discontinued in 1956)

1945 Soil Survey Institute

1947 Forest Research Station T.N.O.

1947 Agricultural Office for Basic Slag

1949 Research Laboratory for Agricultural Chemistry and Advisory Office of the Netherlands Superphosphate Industry

1949 General Netherlands Inspection Service for Seeds of Field Crops and for Seed Potatoes, N.A.K. (Extension of the building)

1949 Central Association for the Improvement and the Supply of Propagating Material of Field Crops

1949 Experimental Farm of the Institute for Research on Varieties of Field Crops

1950 Institute for Phytopathological Research (I.P.O.)

1950 Netherlands Agricultural Museum (Extension of the building)

1951 Drying Research Laboratory (since 1956 Division II of the I.B.V.L.)

1951 Physico-Technical Service for Agriculture

1951 Centre for Agricultural Documentation

1951. Plant Protection Service (Extension of the building)

1951 International Agricultural Study Centre

1952 Institute for Research on Storage and Processing of Horticultural Produce (I.B.V.T.)

1952 Experiment Station of Milling and Baking (Extension)

1952 Foundation for Agricultural Plant Breeding

1952 Foundation for the Improvement of Forest Seeds and Plants

1952 Institute for Potato Storage (since 1956 Division I of the I.B.V.L.)

1953 Cereals Department of the Central Institute for Nutrition Research T.N.O.

1953 Institute of Horticultural Plant Breeding

1953 Dutch Flax Institute

1953 Experimental Farm "De Bouwing" (P.A.W., I.B.S. and I.B.V.L.)

1954 Centre of Agricultural Mechanization:

Division of Agricultural Machinery and Farm Buildings of the Agricultural University

Institute of Horticultural Engineering and the Centre of Horticultural Engineering

Institute of Agricultural Engineering and Rationalization

Central Workshop

1954 Institute for Research on Varieties of Field Crops

1954 Government Seed Testing Station (Extension) 
1955 Centre for Research in Rural Home Economics

1955 Statistics Department T.N.O., Subdivision Wageningen

1955 Lodging House

1955 Plant Nutrition Research Laboratory of the Chilean Nitrate Agricultural Service

1955 Netherlands Grain Centre

1955 Plant Physiological Research Centre

1955 Institute for Land and Water Management Research

1955 International Institute for Land Reclamation and Improvement

1956 Centre for Mathematics in Agriculture

1956 Institute for Biological and Chemical Research on Field Crops and Herbage (I.B.S.)

1956 Experimental Station for Field Crop and Grassland Husbandry (P.A.W.)

1956 Agricultural Office for Basic Slag (Extension)

1956 Institute for Storage and Processing of Agricultural Produce (I.B.V.L.)

1956 Plant Protection Service (new laboratory for testing on disease-resistance of potatoes)

1957 Agricultural Publication Centre

1957 Institute for Phytopathological Research (Extension)

1957 Institute for the Application of Atomic Energy

1957 Institute for Farm Buildings

Most of the older laboratories have been modernized since 1948 . The 49 divisions of the Agricultural University and the 45 autonomous institutes employ 600 research workers and 1600 other persons, all living at Wageningen. Some of the Institutes have also an outside service (e.g. Forest Research Station T.N.O., the Plant Protection Service, the Institute for Phytopathological Research, the Foundation for Agricultural Plant Breeding, the N.A.K., the Soil Survey Institute, the Institute of Agricultural Engineering and Rationalization, etc.). The Laboratory of Bulb Research (Lisse) and the Biological Station (Wijster) are situated outside Wageningen; both institutes are divisions of the Agricultural University.

The guide, "Wageningen, Centre of Agricultural Science" 2), gives an annual survey of the research that is going on. In May 1957 the 12th issue will appear. This directory of all the agricultural institutions of Wageningen is edited in English (the addresses are also given in Dutch, French and German).

\section{AgRicultural EDUCATION}

The Agricultural University is the source of teachers for the agricultural schools in the Netherlands. At the moment there are in the Netherlands 4 agricultural colleges, 3 for horticulture, 1 for tropical agriculture, 1 for silviculture and land improvement, 2 for dairying. In addition there are 47 agricultural, and 10 horticultural winter schools. (The 310 primary agricultural and horticultural schools are headed by school teachers certificated in agriculture or horticulture).

2) H. de HaAx and N. G. UILenburg, Wageningen, Centre of Agricultural Science, 11th edition, 1956, $152 \mathrm{p}$. 
The Agricultural University is also the source of staff for the

Ministry of Agriculture, Fisheries and Food

Agricultural University itself

National Council for Agricultural Research

Autonomous Institutes at Wageningen

Research institutes outside Wageningen

Agricultural and horticultural colleges and secondary schools

Agricultural Extension Service (covering agriculture, horticulture, tenancy, dairying and livestock, poultry farming and bee keeping)

Food Supply

Forest Service, Forest Extension Service and Nature Protection

Government Service for Land and Water Use

Netherlands Land Development and Reclamation Society (Ned. HeideMaatschappij)

Land Improvement and Reclamation Company "Grontmy" Ltd.

Reclamation Project of the Zuiderzee

Agricultural and horticultural societies

Dairy cooperatives

Seed inspection services

Private plant breeding stations

Agricultural and food industries (dairying, brewing, strawboard manufacturing, timber and paper industry, canning industry, oil factories, etc.)

Business life (fertilizers, agricultural machinery, seeds, disease-control products, feeding-stuffs).

Further some 300 graduates of Wageningen are working in foreign countries at/in

Private estates in tropical and sub-tropical countries

Experimental stations

Forest Services

Institutions of higher agricultural education

International organizations

Foreign Agricultural Information Services

The Agricultural University gives graduates an opportunity to studying in the tropics at the "Centre Neérlandais" of the "Centre de Recherches Orstom", Adiopodoumé (Ivory Coast).

Since the foundation of the Agricultural University in 1918, more than 2300 students have completed their studies.

\section{Agricultural EXTENSION}

The Agricultural Advisory Service in the Netherlands is decentralized, but 15 advisory officers in general service (including specialists for seed growing, grassland, farm building, horticultural engineering) live at Wageningen. Most advisory officers, however, are in charge of a district. They received their training at Wageningen. They are the mediators between science and practice. Many young graduates are working in the advisory service under the guidance of the advisory officers. 
The government votes large sums of money for research, education and advisory work.

It is a well-known fact that a concern like Philips - Eindhoven employs hundreds of scientific workers. The management expects them to create new possibilities. The same holds for Wageningen as an agricultural centre.

In general it can be said that every year $\frac{1 / 2}{2}$ per cent of the gross value of the total agricultural production (more than 4,000 million guilders) is spent on the rationalization of agriculture in the Netherlands and the increase of its production.

The activities of agricultural societies and cooperative bodies are also very important.

\section{Wageningen, A transmitting STATton}

Farmers and gardeners are skilled workers; without them Wageningen would be no more than a centre of science; thanks to their power of reception it is an important transmitting station. Large numbers are correspondents in the evaluation of varieties. Many professors and directors on the other hand are presidents, members or advisory members of agricultural boards.

\section{INTERNATIONAL EXCHANGE OF INFORMATION}

It is welcomed that the government and business life stimulate the organization of congresses, symposia or technical meetings, and enable scientific workers to visit them, also when they are held in foreign countries.

Meetings and other forms of international cooperation have increased considerably of late years. Last year 16 international courses and congresses were held in Wageningen.

Since 1951 Wageningen has also an International Study Centre. This centre has devised four different programmes, which aim at imparting agricultural instruction in a way that best suits the needs of the individual student from abroad.

A Instruction during "qualifying" period, to prepare students to follow a normal course of study at the Agricultural University, leading to the degree of "Landbouwkundig Ingenieur" (M.Sc.).

B Specialisation in one or more branches in the field of agriculture, horticulture or forestry.

C Instruction at the College for Tropical Agriculture at Deventer, leading to a degree.

D Participation in annual summerschools on specific subjects.

Annual international meetings during the last four years have brought more than 400 agricultural officers to Wageningen for a training in Methods and Programme Planning in Rural Extension. 